\title{
Commodities, Arbitrations and Equitable Considerations
}

by JACQUES COVO*

THE international trade in basic or agricultural commodities, and more specifically grains and oilseeds, concerns about $22 \%$ of the world production of wheat and $14.5 \%$ of the world production of feed grains. ${ }^{1}$ The deficits of the rest of the world are filled by the USA, Canada, the EC, Australia and Argentina. The world trade in agricultural commodities is 125 million tons which, at an averaged price today of $\$ 125$ a ton, gives a figure of 15,625 million dollars.

For the year 1990-91 the United States alone held about $32 \%$ of the international wheat trade and about two-thirds of the international trade in feed grains. Canada trades about $20 \%$ of the international wheat market, Australia about $12 \%$, and the EC has kept $20 \%$ of international trade in wheat. Argentina enjoys 7\% of world wheat exports. ${ }^{2}$ These numbers change from year to year according to the size of crops and the rate of competitiveness on the world markets. Apart from these five exporting countries, the rest of the world has an insufficient production and imports through centralized national buying agencies only that which is necessary, in order to protect their national production.

During recent years, the principal importers of wheat were: the Far Eastern countries including the People's Republic of China (27 to 30 million tons); Japan ( 5.7 million tons); the former Eastern European countries (2 million tons) and the USSR, which has irregular but strongly increasing needs (30 to 35 million tons for the 1991-1992 period); the African countries and the Near East, (more than 30 million tons); and the European Community (of which the Member States still import 2 million tons a year). ${ }^{3}$

In animal feeding stuffs, the three biggest importers are the USSR (about 22 million tons), Japan ( 28 to 29 million tons), and the EC ( 3.5 million tons). ${ }^{4}$

The majority of import-export transactions is done by the big international trading companies. Among them, contracts are almost always made on the terms of the relevant trade associations' standard forms which 'can run into

* Commodity Trade Arbitrator and International Consultant, Geneva, licencié en droit University of Geneva, Member of the Contracts Committee of the Grain and Feed Trade Association (GAFTA), London. This article is adapted from a paper delivered on October 4, 1991 at the 10th Biennial Conference of the Section of Business Law of the International Bar Association in Hong Kong.

1 M. L. Debatisse Cerealexport (1984), p. 4.

2 'Le Monde' Dossier et Documents No. 186 Le Marché des Céréales (March 1991).

3 'Le Monde', supra (except for USSR).

4 'Le Monde', supra.

ARBITRATION INTERNATIONAL, Vol. 9, No. 1

(C) LCIA, 1993 
more than 200 lines of print and are intended to reflect all aspects of how the trade in any particular commodities is normally conducted'. ${ }^{5}$ These Associations deal with 'physicals', that is, with the commodities themselves, and their contract forms are for physical delivery. By contrast;

'futures trading concerns what is bought and sold on the futures (or terminal) markets of parcels of goods of a specified quantity and quality for delivery in certain specified months in the future. Whereas in physical trading all parties are dealing in goods which are expected to be delivered, in futures trading most of the traders are buying and selling before the delivery dates arrive. However, those dates do arrive and a future can become a physical so that the persons who hold bought notes have to take delivery of actual goods. Likewise, those who have sold have to produce the goods for those who have bought and want to take delivery when the time arrives'. ${ }^{6}$

The world's major associations of basic commodity trade are: the Grain \& Feed Trade Association of London, known under the acronym GAFTA, and the London based Federation of Oils, Seeds and Fats Associations (FOSFA), which cover over $70 \%$ of London commodity arbitration per year; LRBA (London Rice Brokers Association); $;^{7}$ AFOA (American Fat and Oils Association) of New York; PORAM (Palm Oil Refiners Association of Malaysia); and NAEGA (North American Export Grain Association) Washington, DC.

In Europe, historically, trade associations are the continuations of corporatist organizations. At a very early stage, these associations developed their code of practice, general professional conditions and their standard form contracts as well as their arbitration institutions in order to settle their disputes within their own corporation. ${ }^{8}$ Their standard contracts are very widely used throughout the world by the private sector, but they are rarely relied upon by State enterprises, as the latter have their own terms of purchase, usually providing for litigation or arbitration in their own country. These contract forms are for different commodities, different origins, different methods of transportation or different trade terms. ${ }^{9}$ They contain, inter alia, clauses for quality/price allowance allowing a certain percentage of price reduction in case of a given deficiency in the specifications; force majeure clauses; strike and prohibition clauses; default clauses contemplating resale and cover; and, of course, arbitration clauses.

Besides establishing standard contract forms as well as quality standards for their commodities and encouraging uniformity in trade practices, one of the

5 Brain Chapman 'FOSFA International Arbitration' Arbitration International (1986), p. 323.

6 Derek Kirby-Johnson 'Commodity Associations' in Handbook of Arbitration Practice, London (1987), p. 192.

7 For a list of British Commodity Trade Associations, see Arbitration (Commodity Contracts) Order 1979, Part II of the Schedule.

8 Djamal Lakhdari 'International Arbitration and Raw Materials' in New Trends in the Development of International Commercial Arbitration and the Role of the Arbitral and Other Institutions, ICCA Congress Series No. 1, p. 118.

9 James C. Mackie 'Gafta Arbitration Procedures', The Journal of the Chartered Institule of Arbitrators, vol. 56, No. 3 (August 1990) 150, at p. 151. 
major roles of these trade associations is precisely to organize arbitrations under their auspices. A party to an arbitration, whether it be a member or not, who does not comply with an award is blacklisted or its name 'posted', as it is commonly said, in the trade. This is so in the case of English, ${ }^{10}$ German $^{11}$ and Dutch ${ }^{12}$ trade associations' arbitrations. In France, where the commodity trade arbitrations are held under the auspices of an institution autonomous from the trade associations - (namely the Chambre Arbitrale of Paris, the principal French institutionalized commodities arbitration centre)blacklisting is not done by the arbitration institution but by the trade association. ${ }^{13}$

Under the Grain Arbitration Rules of the AAA, the arbitrators are appointed from a standing list. But, in London GAFTA, FOSFA and LRBA arbitrations, the arbitration is initiated by the claimant designating an arbitrator, and so advising the other party. If the arbitrator declines to serve, a substitute may be named; if the other party does not appoint an arbitrator, the association may, upon application, do so on its behalf. If the two designated arbitrators cannot agree on a third one, the association may make the nomination. ${ }^{14}$ The third arbitrator is Chairman of the Tribunal under the rules of GAFTA, and Umpire under the rules of FOSFA. In case of a disagreement on the issue, the two party-appointed FOSFA arbitrators officially act, from the time of their disagreement, as advocates. The principle of the arbitrator/advocate system is recognised in Wessanen's Koninklijke Fabrikien v. Isaac Modiano Brother $\mathcal{E}^{2}$ Sons $L t d .{ }^{15}$ But one writer has said: ${ }^{16}$

In the commodity trades it was for long accepted that a party who had appointed 'his' arbitrator would expect that arbitrator to do his very best for his appointer's case and to make an award that would be as favourable as possible to him. There did not seem to be anything wrong in this because the other party's arbitrator would be doing his best for his appointer and if the arbitrators failed to reach agreement, they would call in an umpire before whom each could present his party's case as an advocate. This was widely accepted as 'arbitration' although it now seems more like a form of amiable composition at least until an umpire is called in. There are several disadvantages in this system. It encourages advocacy. It tends to give an advantage to parties who appoint experienced and able arbitrators over those who appoint less senior men: this is not only unfair but it tends to restrict the spread of experience and to concentrate work in the hands of a small number of well-known persons, thus leading to the problem of the 'busy arbitrator' and resulting delays. Furthermore, it can lead to unofficial but commercial and undesirable links between parties and arbitrators.

10 GAFTA Arbitration Rules of 1.6.1991, Rule 15:1; FOSFA Rules of Arbitration and Appeal, Rule 10 (c).

11 Verein der Getreidehändler des Hamburger Börse e.V. Hamburg Arbitration Rules of 1.8.1978, Art. 33.

12 Conditions of the Rotterdam Grain Exchange 1920, Art. 51.

13 Syndicat de Paris du Commerce et des Industries des Grains, Produits du Sol et Dérivés, Additif aux Formules de Paris of 1 July 1991, Art. 20.

14 Albert Slabotzky, Grain Contracis for US and Canada, p. 90.

15 [1960] I WLR 1243.

16 James C. Mackie unpublished monograph submitted to the Chartered Institute of Arbitrators showing, inter alia, how commodity arbitration developed into institutionalised arbitration. 
In commodity arbitrations a link exists per se as the commodity trade arbitrator is - as is the case for experts of any specific field - 'almost necessarily colleague with or competitor of one of the parties'. ${ }^{17}$

Short and strict time limits are provided for initiating a claim by the Arbitration Rules of GAFTA and FOSFA, and failure to do so may result in barring the claim, unless the arbitrators exercise their discretionary power to extend time. This is one of the very rare situations where GAFTA and FOSFA contracts implicitly contemplate equitable considerations. These matters of extension of time-limits to claim arbitration, or to prevent a claim from lapsing through inaction, are then decided according to the subjective moral conscience of the arbitrators, and not according to pre-established rules. An arbitrator would commonly look at the sort of reasons that the Court would take into consideration (as in the case of section 27 of the Arbitration Act 1950) in deciding whether or not he should allow an extension of time to initiate a claim.

Institutionalized commodities arbitrations in Europe are normally two-tier. The party dissatisfied with an award may lodge an appeal, which is heard by the Board of Appeal, usually comprised of five arbitrators appointed by the association. Under Rule 7(a) of the FOSFA Rules of Arbitration and Appeal, 'the appeal shall be determined by a Board of Appeal of five members, appropriately appointed by the Federation from the Arbitration and Appeal Panel'. ${ }^{18}$ In practice, the appointment is made by the Executive Committee. In GAFTA, the two persons with the highest number of votes go on the Board of Appeal, the three other members being selected from a roster maintained for that purpose ${ }^{19}$ and composed of members elected by the Council after passing the prescribed examination. ${ }^{20} \mathrm{On}$ appeal, the case is heard de novo and new evidence can be submitted for the first time, provided notice is given to the other side in reasonable time before the hearing.

At the Chambre Arbitrale of Paris, the original award is called 'project of award' and becomes a final award after time for appeal has elapsed. ${ }^{21}$

At GAFTA and FOSFA appeal hearings, parties are usually represented by the arbitrator appointed at the original arbitration. The system has been criticized in Continental Europe. ${ }^{22}$ In France, the Court of Appeal of Rheims has held that the fact that an opponent's representative before the GAFTA Board of Appeal was the arbitrator appointed by it at the first tier arbitration did not constitute a violation of French international public policy. ${ }^{23}$ Members

17 Edmorid Pittard, Guide du témoin, de l'expert et de l'arbitre (Geneva 1910), reedited by the Swiss Chamber of Technical and Scientific Legal Experts (CSEJ), Lausanne.

18 FOSFA Rules of Arbitration and Appeal of 1.10.1990, Rule 7(a).

19 Derek Kirby-Johnson, International Commodity Arbitration (1991), p. 260.

Mackie, op. cit., at p. 152, n. 9.

Chambre Arbitrale de Paris, Règlement d'Arbitrage 1.1.1987, Art. 17.

Robert Van Velden 'English Commodity Arbitration, A Foreigner Looking Around in London' in The Art of Arbitration: Essays on International Arbitration, Pieter Sanders (1982), 95, at p. 107.

23 Denis Coakley Ltd (UK) v. Société Michel Reverdy, decision of July 23 1981, reported in 1982 Revue de l'Arbitrage at p. 303. See also Chapman, op. cit., supra, p. 325, n. 5. 
of the legal profession cannot represent the parties at the original arbitration. They can do so only at appeals, if they have obtained leave of the Board of Appeal. In-house lawyers of trading companies do not need such leave. If subtle points of law are involved and a request is made to the Board for a reasoned award with a view to judicial review, it is likely that the application for 'legal representation' will be accepted (for example, in case of issues of waiver or estoppel). In his recent book Commodity Arbitration Today, Derek Kirby-Johnson characterizes the role of lawyers in trade arbitration as 'interesting', ${ }^{24}$ as their role is played behind the scenes.

Typical situations which give rise to commodity arbitration are: formation of contract; problems of interpretation, such as a clause on warehousing expenses, commonly called 'carrying charges', or on vessel's demurrage or extra waiting time at load port for FOB, or at port of discharge for CIF, contracts; the meaning and value of documents; force majeure and import/export prohibitions; the ascertaining of the day of the breach so as to ascertain the current market or default price on that day; whether or not a market existed; problems of price allowances for inferiority in quality or misdescription.

Equitable considerations are often relied upon in commodity arbitrations in the United States. In Continental European countries arbitration in equity or ex aequo et bono, where arbitrators act as 'amiable compositeur', is an institution in itself. However, such an arbitration does not exist in English law, where arbitration is subject to the supervisory jurisdiction of the Courts. But does this mean that the British business community rejects arbitration in equity as a foreign sociological reality?

The prominent French jurist Marc Ancel, in an article published in 1961 under the title of Valeurs actuelles en droit comparé, ${ }^{25}$ said that 'many differences in methods and techniques, however important or irreducible they may be, are nothing other than particular means through which a common reality expresses or tries to express a conception, or at least an analogous conception, of fundamental rules of social behaviour'. Considering that the common reality here is the need of the business community for equitable considerations in arbitration, and the differences between the English and Continental European systems of arbitration as to equity, the two systems should have their own tools to express their own conception of reality. This is confirmed by Eric Loquin, in $L$ 'amiable composition en droit comparé et international,$^{26}$ who states that: 'In a hostile legal milieu, a phenomenon of an arbitration freed from the strict application of the rules of law has succeeded to manifest and impose itself in practice, by different means, certainly, but by producing equivalent results to those of arbitration in equity. In practice, British

\footnotetext{
24 Kirby-Johnson, supra, p. 7, n. 19.

25 Marc Ancel 'Valeurs Actuelles en Droit Comparé' in Legal Essays in Honour of H. E. Yntema, Leyden (1961), quoted by Eric Loquin 'L'amiable composition en droit comparé et international', Litec (1980), p. 104.

26 Loquin, op. cit., p. 348 , n. 25.
} 
merchants have, in fact, received from arbitration the same services as their Continental equivalents. And arbitration responded to this expectation'.

Despite a legal environment hostile to equitable considerations in English arbitrations, there were two elements which, when combined, allowed trade arbitrators a vast area of freedom vis-à-vis the judiciary, and which enabled them to decide in fairness and good moral conscience. These were, until the English Arbitration Act of 1979, the absence of duty to give reasons, coupled with the small percentage (only $2 \%$ ) of awards subject to what is today known as the 'old special case procedure' for the determination of a question of law. ${ }^{27}$ Since that time, the Arbitration Act 1979 contemplates, in Section $1(3)$, a limited right of appeal to the High Court on questions of law with leave of the Court (or agreement of the parties, which is in fact never given by the party who won the arbitration) and obliges the arbitrators to state reasons if this is requested by the parties. However, the difficulty in remitting the award for the statement of arbitrators' further reasons is such that, coupled with the small number of cases which qualify for the leave of the Court for a judicial review of the award, this tends to give the arbitrators almost the same freedom as before 1979. Also, the Court will not grant leave on the question whether there was any evidence on which an arbitrator could arrive at a particular finding of fact ${ }^{28} \mathrm{~A}$ Dutch lawyer has commented that basically the situation, before and after 1979 , has remained the same. ${ }^{29}$

Within the framework of this freedom, equitable considerations, when taken into consideration, are in practice not reasoned. Trade arbitrators are 'commercial men', ${ }^{30}$ experts as to facts, who have a thorough knowledge of the standard form contracts and their usages, and who are usually not inclined to enter into problems of construction. Hence - and a fortiori - there is a reluctance to give reasons in equitable matters since 'the arbitrator in equity is an arbitrator adjudicating on the basis of rules of law, but with the duty to show particular sensitivity, which may even lead him to go further than the law provides. This implies that the reasoning of the arbitrator in equity starts in law and develops in the criticism of law' ${ }^{31}$ Compared to reasoning in equity, legal reasoning has been qualified as 'narrow' by the late Professor René David. ${ }^{32}$

Another reason why equitable considerations are not reasoned in the awards is that, as a matter of principle, trade arbitrators, being businessmen, do not like to refer explicitly to moral considerations: to take an example, a defaulting buyer makes an offer of repurchase at well above the actual market

\footnotetext{
27 Loquin, op. cit., supra, p. 11.

28 ICCA Yearbook, vol. XIV, part IV, Recent Developments in Arbitration Law and Practice: England, by Sir John Steyn and V. V. Veeder, at p. 506.

Van Velden, op. cit., at p. 99, n. 22.

Pando Compania Naviera SA v. Filmo SAS [1975] Lloyd's Rep. 560.

Gerardo Broggini 'Réflexions sur l'équité dans l'arbitrage international' in 2 Swiss Arbitration Association Bulletin (1991) 95, at p. 108.

32 René David 'L'Arbitrage dans le commerce international' (1982), p. 464.
} 
price to an innocent seller who no longer has the goods at a time when goods are not available on the market, with a view to reducing the damages payable on the ground that the seller should have accepted the offer in mitigation. In arriving at the current market value for assessing damages, trade arbitrators' reaction would most probably be to disregard, but not to comment on the offer made in bad faith.

One fundamental issue in commodity export contracts where equitable considerations are not taken into consideration is that of inspection certificates under clauses making them final and conclusive for the determination of the conformity of quality or weight. Inserted by merchants with the idea of reducing as much as possible disputes on quality or quantity, these clauses are held valid. In Toepfer v. Continental Grain Co. ${ }^{33}$ US Federal Authorities issued a certificate of quality at loadport which did not correspond to the quality of the goods actually discharged at destination. Although at a later stage the goods were confirmed by US Authorities as being of a lower quality, the Court of Appeal upheld the finding of the GAFTA Board of Appeal that the original certificate was final and binding irrespective of the accepted mistake in the inspection certificate by the surveyor. The rationale behind this decision is that, whenever two persons agree to refer a matter to a third person for decision and further agree that his decision is to be final and binding upon them, then, as long as he arrives at his decision honestly and in good faith, the two parties are bound by it. They cannot re-open it for mistake or error on his part or for any reason other than fraud or collusion. ${ }^{34}$ The reason for the rigid application of these clauses by trade arbitrators seems to be that they are generally inclined to apply the law in the most straightforward manner, when as here, it is unambiguous, whereas equitable considerations are taken into consideration for cases presenting legal subtleties.

Similarly, in a GAFTA Arbitration (which became public, as the result of judicial review by the Commercial Court) a defaulting seller was required to pay damages irrespective of the amount of the performance bond cashed by the buyer on the straightforward reasoning that the bond was independent from the contract. The decision was overturned by the Court which held that on the construction of the default clause credit had to be given for the guarantee. ${ }^{35}$

If under 'certificate final' clauses equitable considerations have not so far modified the harshness of the conclusiveness based on the findings of the inspection certificate, there are nevertheless situations where this type of certificate may not be final and binding: the inspection certificate must be obtained without fraud or collusion with the certifier. The certificate must also relate to contract goods: in a situation where cargo was inspected but the

[1974] I Lloyd's Rep. 11.

Arenson v. Arenson [1973] 2 Lloyd's Rep. 104, at p. 107 (C.A.) (revd. [1977] A.C. 405).

35 Baytur S. A. v. Moona Silk Mills, December 20, 1984 (Mustill J.) noted by J. Covo in 1985 J.B.L. 324; Schmitthoff's Export Trade (9th ed.) p. 452. 
consignment tested was not the consignment which was eventually shipped the 'certificate final' doctrine was held not to apply. ${ }^{36} \mathrm{~A}$ further condition for the 'certificate final' doctrine to apply is that there must be strict compliance of the certificate with the terms of the contract. There is no room for inspection certificates which are 'almost the same' as those required by the contract. Even if the certificate conclusively complies as to quality, goods may be rejected and damages claimed by the buyer, if goods do not meet the contractual description. ${ }^{37}$

A situation where the decision of trade arbitrators is often based on fairness and good conscience, is with respect to awarding damages under sales contracts or, in practice, the ascertaining of the current market price on the day of default, as provided by almost identical standard default clauses of the standard form contracts of trade associations. For example, where six contracts are exhibited as evidence of the price of the goods on a given date, with respectively three hypothetical prices at $\mathrm{US} \$ 100,1$ at 99,1 at 98,1 at 95 , the reaction of a person without knowledge of the trade would be to add the figures and divide them by 6 . The skilled and experienced arbitrator will achieve a more accurate result by selecting a price which is more relevant than the others, because he may find some of the prices, for a variety of reasons, not representative. His reasons to prefer such a price rather than another will be based on his knowledge of the trade and considerations of fairness. This is even more true when the price to be ascertained does not concern that of a cargo sold on a given date, but the price at which it could have been sold. In these cases trade arbitrators do not seek to justify their calculations by strict legal rules $^{38}$ but declare that on the evidence before them, the price is such.

Another situation where equitable considerations are relied upon in commodity arbitrations is the case of goods sold in bulk with certain specifications (for instance, their protein or fibre content) and which are found mixed with other commodities at loading, in a situation where the contract does not provide for damages or anything else in case of admixture of goods. (Lack of provisions on admixture is not surprising as in overseas sales risk passes from the seller to the buyer as from shipment, and admixture normally takes place during the sea transit. It thus becomes a matter arising under the bill of lading between the receiver, usually a CIF buyer under the contract, and the shipowners). To resist a buyer's claim for an allowance because of the admixture, the seller may invoke conformity of the goods with the contractual specifications and the 'certificate final' doctrine. The buyer's reason for the claim is only because the mixed goods he bought are worth less than the contract goods: he cannot prove having suffered damages if the goods are not

Cauwenberghe v. Tropical Products [1986] 1 Lloyd's Rep. 535.

Sale of Goods Act 1979, S. 13(1).

Craig Park and Paulsson, International Chamber of Commerce Arbitration (1984), p. 97, quoting ICC Case 344 of 1981 on the determination of price in oil sales contract. 
resold to the market for determining their price, and if his own buyers - the receivers in the chain of contracts - do not complain, since they usually do not analyse the relatively small parcels delivered and accepted by them. Despite the buyer's lack of evidence as to damages, these cases are approached on a moral basis and the buyers are compensated by a price allowance on the unspoken understanding that, from their trade knowledge, arbitrators were aware that the admixture was caused not by factors proper to the commodity itself or during the sea transit, but because the initial sellers at the country of origin deliberately mixed the commodity with another commodity (for example soyabean meal and wheat pollards), which they can no longer sell to the principal client country in view of recent regulations restricting its importation there.

The measure of damages in such a case is given by section 53(3) of the Sale of Goods Act 1979. In case of breach of warranty of quality, the loss is prima facie the difference between the value of the goods at the time of delivery and the value they would have had if they had fulfilled the warranty. The admixed goods are then found rejectable for misdescription (section 30(4)), the breach of condition is found to be treated as breach of warranty by the buyer who accepted the goods, the certificate of analysis constitutes evidence of the lesser value of the goods because of the admixture and, 'as such', is judged sufficient for the granting of an allowance to the buyer.

The system of allowances in case of difficulty in bringing evidence of the damage is recognized by English Courts as common practice in the commercial world. ${ }^{39}$ This relates to a situation where a party did actually suffer damage but has difficulty proving it, which is in fact a completely different case. But this situation should not be surprising, as equity in the hands of arbitrators is different from equity in the hands of judges. In the service of law, judges serve morality only to the extent that the former has adopted the precepts of the latter. ${ }^{40}$ The position of the arbitrator is different from that of the judge. As a private person holding his powers from two persons, he is not - in any case, at least not essentially - at the service of the law. This fact allows him to be conscious of the fact that the parties rely on his sense of equity in which morality occupies a good part. ${ }^{41}$

To illustrate the impact of equitable considerations in commodity arbitrations, it is interesting to note the comment of a past president and arbitrator of a leading London trade association: 'What is in fact being said is that a large majority of the disputes that do arise raise no points of law and simply revolve around what is considered to be a reasonable commercial interpretation of a particular set of circumstances ${ }^{42}$ and the duty of trade arbitrators is

\footnotetext{
39 Benjamin's Sale of Goods, 3rd ed. (1987), p. 486.

40 Pierre Mayer 'La Règle morale dans l'arbitrage international' in Etudes offertes à Pierre Bellet (1991), p. 378 .

41 Mayer, op. cit., supra.

42 Chapman, op. cit., n. 5.
} 
'to use their commercial experience to adjudicate on the evidence placed before them (it goes without saying they must do so according to the law) ${ }^{43}$

\section{CONCLUSION}

Although there are restraints on the desire of arbitrators to take equitable considerations into account, these restraints being caused mainly by the supervisory power of the judiciary and the desire to respect strictly the wording of the contract, we have seen that equitable considerations play, in the English arbitration system where they are not supposed to exist, an important role. This, I believe, provides the answer to the question of whether or not every arbitrator is a hidden equitable arbitrator.

43 Chapman, op. cit., p. 332, n. 5. 